antibiotic whose range of antibacterial activity is in most respects similar to that of aureomycin, may have slight anti-tuberculous activity. This, however, is manifest, if at all, only with very large doses, and no results of clinical trials are yet available.

\section{Summary}

At present the administration of streptomycin intramuscularly concurrently with para-amino- salicylic acid by mouth is the standard method of 2 anti-bacterial treatment in pulmonary tuberculosis. $\frac{2}{8}$

The investigations which have led to the general $\cong$ adoption of this combined treatment are outlined and current indications for its use briefly discussed.

Though streptomycin has serious toxic effects? and limitations imposed by the ability of tubercle $ㄷ$ bacilli to become resistant to its action, investiga- $\frac{\bar{\omega}}{\sigma}$ tions of some newer antibiotics hold no promise $\mathbb{\nabla}$ that any so far discovered can replace it.

\section{BIBLIOGRAPHY}

Medical Research Council Trials

Thiosemicarbazones

'Streptomycin Treatment of Pulmonary Tuberculosis' (1948), Brit. med. F., il, 769 .

'Streptomycin in Acute Miliary Tuberculosis' (1950), Lancet, i, 841 .

'Treatment of Pulmonary Tuberculosis with Streptomycin and Para-amino-salicylic Acid '(1950), Brit. med. $\mathscr{F}$., ii, 1073.

'Streptomycin Treatment of Tuberculous Lesions of the Trachea and Bronchi' (195I), Lancet, i, 253.

'Prophylactic Streptomycin in Thoracoplasty Operations' (1951), Thorax, 6, 17 .

\section{Intermittent Streptomycin Regimes}

JAMES, L. A., SIDES, L. J., DYE, W. E., and DEYKE, V. F. (1951), Amer. Rev. Tuberc., 63, 275.

TEMPEL, C. W., HUGHES, F. J., MARDIS, R. E., TOWBIN, M. N., and DYE, W. E. (195I), Amer. Rev. Tuberc., 63, 295.

\section{Dihydrostreptomycin}

Series of papers (1948) in Amer. Rev. Tuberc., 58, 479-536.

O'CONNOR, J. B., CHRISTIE, F. J., and HOWLETT, K. S. (I95I), Amer. Rev. Tuberc., 63, 3 I 2.
Series of papers (1950) in Amer, Rev. Tuberc., 61, 1-38.

HINSHAW, H. C., and MCDERMOTT, W. (1950), Amer. Rev.C Tuberc., 61, 145 .

Neo mycin

WAKSMAN, S. A., and LECHEVALIER, H. A. (1949), Science, $\omega$ 109, 305.

WAKSMAN, S. A., HUTCHINSON, D. and KATZ, E. (1949), $\omega$ Amer. Rev. Tuberc., 60, 78 .

CARR, D. T., PFUETZE, K. H., BROWN, H. A., DOUGLASS, $63,427$.

Viomycin

Series of papers (195I) in Amer. Rev. Tuberc., 63, 1-6r.

Terramycin

HOBBY, G. L., LENERT, T. F., DONIKIAN, M., and PIKULA, Ф D. (I95I), Amer. Rev. Tuberc., 63, 434. B. E., and KARLSON, A. G. (1951), Amer. Rev. Tuberc,. 응

\title{
DEEP PELVIC RETRACTOR
}

Good retraction is' an essential for deep dissection in the pelvis.

The retractor here illustrated, made for me by Messrs. John Bell \& Croyden, has certain advantages.

The long hollowed blade with a flange at its lower end, is of great assistance in holding forward the pelvic viscera in operations such as combined excision or anterior resection of the rectum.

E. G. MuIR, London, W.I.

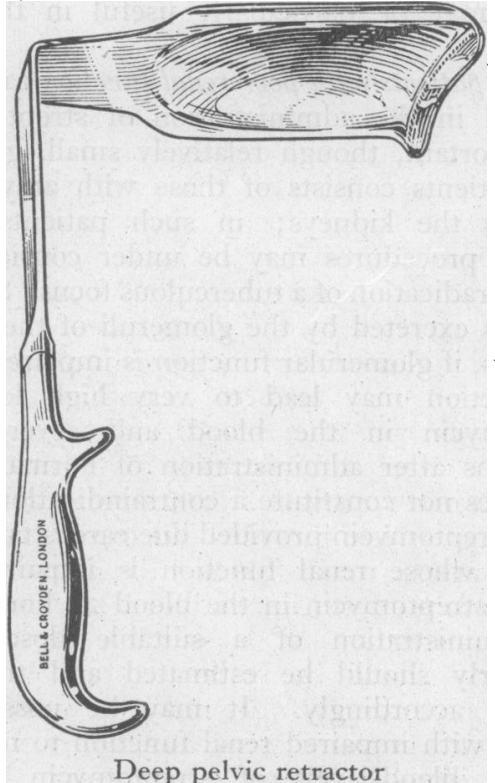

